\title{
Vasoactive Intestinal Peptide Stimulates Neuropeptide Y Gene Expression and Causes Neurite Extension in PC12 Cells through Independent Mechanisms
}

\author{
R. A. Colbert, D. Balbi, A. Johnson, J. A. Bailey, and J. M. Allen \\ Physiological Laboratory, University of Cambridge, Cambridge CB2 3EG
}

\begin{abstract}
Vasoactive intestinal peptide (VIP) is widely recognized as a regulator of tyrosine hydroxylase via a mechanism of transsynaptic activation. Subsets of adrenal medullary cells and postganglionic sympathetic nerves coexpress the peptide neurotransmitter neuropeptide $Y$ (NPY) with catecholamines. Using PC12 cells transiently expressing a fusion gene in which the bacterial enzyme chloramphenicol acetyltransferase (CAT) is under the control of 700 base pairs of the 5 flanking region of the NPY gene, we have studied the role of VIP and the related peptide pituitary adenylate cyclase activating peptide (PACAP) in regulating NPY gene transcription. Both VIP and PACAP stimulated expression of the NPY gene through activation of CAMP-dependent protein kinase. PACAP was 1000-fold more potent in eliciting this response compared to VIP and activity resided in its $\mathbf{N}$-terminal 27 amino acids. Both VIP and PACAP caused a subpopulation $(\sim 50 \%)$ of $P C 12$ cells to undergo profound morphological changes in that the cells extended long, slender neurites with prominent growth cones. This change in morphology was unaffected by preincubating cells with inhibitors of either CAMP-dependent protein kinase or calcium/ phospholipid-dependent protein kinase. A trophic role for either VIP or PACAP in regulating sympathetic nerve function is proposed.
\end{abstract}

IKey words: vasoactive intestinal peptide, pituitary adenylate cyclase activating peptide, neuropeptide $Y$, transsynaptic activation, neurite extension, cAMP-dependent protein kinase]

Transsynaptic activation of tyrosine hydroxylase (TH) within sympathetic autonomic ganglia is a widely recognized event and is implicated in restoration of synaptic stores of catecholamines following depolarization. The immediate effect is an increase in activity of existing pools of TH (Zigmond et al., 1989) but, ultimately, higher levels of the enzyme are induced through increases in TH mRNA levels and activation of the gene (Kilbourne et al., 1992) (McKeon and Zigmond, 1993) (WesselsReiker et al., 1991). Although cholinergic transmission may be the principal factor involved in this regulation, a role for other noncholinergic neuromodulators within preganglionic nerve ter-

Received Dec. 13, 1993; revised Apr. 27, 1994; accepled May 26, 1994.

This work was supported by a grant from the Wellcome Trust.

Correspondence should be addressed to Dr. J. M. Allen, Physiological Laboratory, University of Cambridge, Downing Street, Cambridge CB2 3EG, UK.

Copyright (C) 1994 Society for Neuroscience $0270-6474 / 94 / 147141-07 \$ 05.00 / 0$ minals in controlling postganglionic sympathetic nerve function has been implicated for some time. Initial studies demonstrated electrophysiological responses in frog sympathetic ganglia that could not be accounted for by cholinergic transmission (Nishi and Koketsu, 1968). However, the existence of an analogous response in mammalian sympathetic ganglia was initially suggested by Chen (1971) and was subsequently demonstrated electrophysiologically (Ashe and Libet, 1981). A specific role for the regulatory peptide, vasoactive intestinal peptide (VIP), a 28 amino acid peptide (Said, 1982), has been suggested by its effect on the accumulation of cAMP in rat sympathetic ganglia (Volle and Patterson, 1982; Ip et al., 1985) and by its stimulation of tyrosine hydroxylase activity in rat superior cervical ganglia (Ip et al., 1982, 1985; Malhotra et al., 1987). This peptide has been localized to nerve terminals within both bovine adrenal medullary tissue (Yoshikawa et al., 1990) and rat superior cervical ganglia (Sasek and Zigmond, 1989). Furthermore, VIP immunoreactivity (VIP-IR) has been demonstrated in nerve cell bodies of the intermediolateral column of the spinal cord (Krukoff, 1986; Baldwin et al., 1991). Infusion of VIP causes release of catecholamines from adrenal medullary tissues (Malhotra et al., 1987, 1988; Misbahuddin et al., 1988). VIP activates adenylate cyclase and through this pathway increases TH activity (Roskoski et al., 1989) and TH mRNA levels (Wessels-Reiker et al., 1991).

Subsets of postganglionic sympathetic nerves and adrenal medullary cells (Varndell et al., 1984) contain neuropeptide $Y$ (NPY) (Tatemoto, 1982; Colmers and Wahlestedt, 1993), a 36 amino acid regulatory peptide, where it coexists with catecholamines and is released during nerve stimulation (Allen et al., 1984; Potter, 1988). Studies on the regulation of the NPY gene have concentrated principally on the role of NGF, phorbol esters, and cAMP (Sabol and IIiguchi, 1990; Balbi and Allen, 1994). Transsynaptic regulation of NPY mRNA levels have been demonstrated (Schalling et al., 1989; Hanze et al., 1991), and it has been suggested that the NPY gene may be regulated, in part, by noncholinergic factors (Schalling et al., 1991). However, little is known of the role of peptide neurotransmitters localized in preganglionic nerve terminals in regulating NPY gene expression. In view of the proposed role of VIP in transsynaptic regulation of the enzyme involved in catecholamine biosynthesis, we have studied the effect of this peptide neurotransmitter on transcription of the NPY gene using PC1 2 cells (Greene and Tischler, 1976) as a model of chromaffin cells.

\section{Materials and Methods}

Nerve growth factor (2.5S) was purchased from Serotec, VIP was obtained from Cambridge Research Biochemicals, and Pituitary Adenylate 


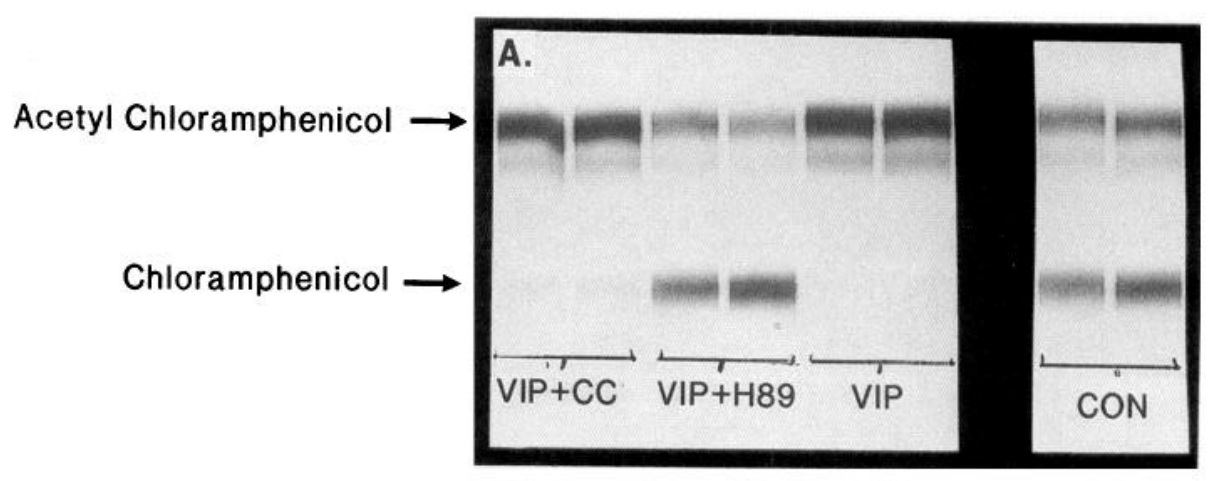

Figure 1. Activity of CAT in PC12 cell extracts transiently expressing NPYCAT fusion gene. $A$, Comparison of untreated cells $(C O N)$ with activity in cells treated with VIP either alone or following preincubation of cells with the PKA inhibitor $\mathrm{H}-89$ or the PKC inhibitor calphostin $\mathrm{C}(C C)$. $B$, The effect of increasing concentrations of $\mathrm{H}-89$ on VIP induction of NPY promoter with VIP. $3.3,3.3 \mu \mathrm{M} \mathrm{H}-89 ; 10,10 \mu \mathrm{M} \mathrm{H}-89 ; 30$ $30 \mu \mathrm{M} \mathrm{H}-89$.

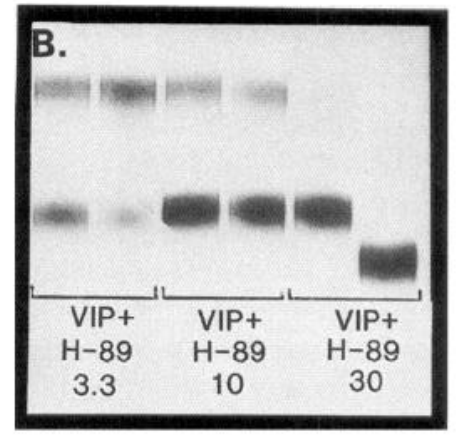

Cyclase Activating Peptide (PACAP) and its fragments from Peninsula Laboratories. NGF and the peptides were dissolved in DMEM, aliquoted, and stored at $-70^{\circ} \mathrm{C}$ until use.

PC12 cell cultures. Cells were grown in polystyrene tissue culture dishes (Nunc, GIBCO), coated with air dried rat tail collagen (Sigma), in Dulbecco's Modified Eagle's Medium (DMEM; GIBCO) supplemented with $10 \%$ heat-inactivated horse serum (GIBCO), $5 \%$ fetal calf serum (GIBCO), $2 \mathrm{~mm}$ glutamine (Sigma), $100 \mathrm{mg} / \mathrm{ml}$ streptomycin (GIBCO), and $100 \mathrm{U} / \mathrm{ml}$ penicillin (GIBCO).

Chloramphenicol acetyl transferase (CAT) assay. A fragment of DNA $(\sim 700 \mathrm{bp})$ of the $5^{\prime}$ flanking region of the NPY gene was obtained by polymerase chain reaction (PCR). The downstream primer $\left(3^{\prime}\right)$ was located in the middle of exon 1, thus including the cap site of the NPY gene but avoiding the first initiation codon (Larhammar et al., 1987). The upstream $\left(5^{\prime}\right)$ primer was designed to start at -674 relative to the transcription start site. The PCR product was first subcloned into the HincII site in the polylinker region of the vector pGEM 3Z(+) (Promega), in order to access suitable cloning sites at both ends of the PCR product, and then subcloned into the PstI and XbaI sites in the polylinker of pCAT basic vector (Promega). The sequence of this construct was verified and is referred to as NPY-CAT (Balbi and Allen, 1994).

DNA was transfected into PC1 2 cells ( $70 \%$ confluent plate) using a standard calcium phosphate precipitation method (Kingston, 1987). All experimental conditions were performed in duplicate. The following day, the various compounds described in the results section were added to the incubation medium. In the case of the inhibitors, the cells were incubated with these for 60 minutes before any subsequent additions. After incubation for a further $48 \mathrm{hr}$, cells from each plate were harvested in phosphate buffered saline (PBS). After pelleting, the cells were lysed by addition of $100 \mu \mathrm{l}$ of $250 \mathrm{~mm}$ Tris ( $\mathrm{pH} \mathrm{7.8)}$ and three freeze-thaw cycles. Endogenous de-acetylase activity was inactivated by heating to $65^{\circ} \mathrm{C}$ for $10 \mathrm{~min}$. The amount of total protein in each sample was determined photometrically using the Bradford Bio-Rad procedure. Aliquots of each extract representing equal amounts of protein were then assayed for CAT activity by measuring the acetylation of ${ }^{14} \mathrm{C}$-labeled chloramphenicol (Amersham) in the presence of excess acetyl coenzyme A to act as acyl donor. Acetylated chloramphenicol and chloramphenicol were extracted in ice cold ethyl acetate and separated on thin layer chromatography plates using a solvent mix of 9:1 chloroform:methanol.

The plates were exposed to x-ray film (Fuji RX) for $24 \mathrm{hr}$. For quantitation, the optical density of the bands on the film was measured using a Molecular Dynamics densitometer and the density of each band above background was calculated.

\section{Results}

Transfection of PC12 cells with NPY-CAT resulted in measurable levels of CAT activity in cell extracts. No CAT activity was detected in nontransfected cell extracts or in cells transfected with the basic CAT vector (lacking the NPY promoter) (Balbi and Allen, 1994). Addition of VIP (5 $\mu \mathrm{M}$, Peninsula Laboratories) to PC12 cells transfected with the NPY-CAT fusion gene resulted in a marked increase in the measurable CAT activity compared to controls (Fig. 1A). Pretreatment of $\mathrm{PC} 12$ cells with $\mathrm{H}-89$, an inhibitor of cAMP-dependent protein kinase (PKA) $(10 \mu \mathrm{M}$; Calbiochem) (Fig. $1 \mathrm{~A})$ blocked the effect of VIP on induction of NPY gene transcription in a concentrationdependent fashion (Fig. $1 B$ ). H-89 specifically inhibits PKA with a $K_{i}$ of $48 \mathrm{nM}$, whereas its inhibition constant for PKC is 31.7 $\mu \mathrm{M}$. Addition of a specific inhibitor of calcium/phospholipiddependent protein kinase (PKC), calphostin C (1 $\mu \mathrm{M}$; Calbiochem) (Shimamoto et al., 1992), reduced the effect of VIP on NPY-CAT to a small but reproducible extent (Fig. 1A). Calphostin $\mathrm{C}$ is a highly specific inhibitor of $\mathrm{PKC}$ with a $K_{i}$ of 50 nM. Its inhibition constant for PKA is greater than $50 \mu \mathrm{M}$. The threshold concentration for VIP induction of NPY gene transcription was $5 \mathrm{nM}$. Increasing concentrations above this threshold resulted in progressively higher levels of CAT activity, indicating that the effect of VIP on the promoter region of the NPY gene was concentration dependent (Fig. 2).

The effect of VIP on the NPY gene was then compared to that of forskolin $(20 \mu \mathrm{M}$; Sigma). Both VIP and forskolin increased CAT activity in cell extracts, and this increase was inhibited by $50 \%$ following preincubation of cells with $5 \mu \mathrm{M} \mathrm{H}-89$. Preincubation with calphostin $\mathrm{C}$ resulted in a small but consistent decrease in the subsequent response of NPY-CAT to either VIP or forskolin (Fig. 3).

Pituitary adenylate cyclase activating polypeptide is a 38 amino acid peptide which is a member of the secretin/glucagon/ VIP peptide family (Arimura, 1992). Addition of PACAP to 


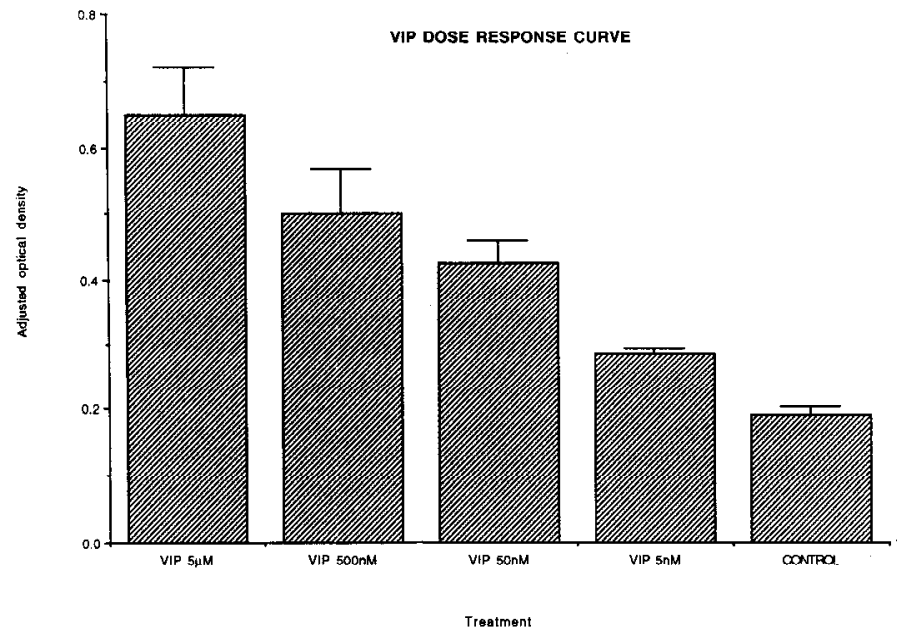

Figure 2. The effect of increasing concentrations of VIP from $5 \mathrm{~nm}$ to $5 \mu \mathrm{M}$. Optical density of acetylated chloramphenicol was adjusted for background of the film. Results represent mean of duplicate experiments.

transfected $\mathrm{PC} 12$ cells resulted in responses similar to the effect of VIP. However, the effect of PACAP was observed at considerably lower concentrations. Thus, the threshold concentration for PACAP to stimulate activity of the NPY-CAT fusion gene was 5 pM. Increasing concentrations of PACAP resulted in higher levels of CAT activity directed by the NPY gene, until a maximum response was reached at $5 \mathrm{nM}$ (data not shown). Two fragments of PACAP, 1-27 and 16-38, were tested for effect on NPY-CAT activity. The N-terminal fragment $1-27$ was found to have a positive effect although the threshold for this response was higher (50 pM) than for the full-length molecule (data not shown). The C-terminal fragment (16-38) had no effect on the NPY-CAT activity (Fig. 4). Preincubating cells with H-89 completely blocked the response of NPY-CAT to both PACAP and its 1-27 fragment (Fig. 4).

Incubation of PC12 cells with VIP $(5 \mu \mathrm{M})$ resulted in a marked change in their appearance, converting them over $2 \mathrm{~d}$ of incubation into cells that resemble neurons-the cells flatten and extend long, slender neurites with prominent growth cones (Fig. 5). The response in terms of neurite extension was apparent within $6 \mathrm{hr}$ of applying VIP. The threshold concentration of VIP required to produce the morphological response was higher than that required to alter NPY gene transcription. Thus, 500 nм VIP resulted in neurite extension whereas addition of 50 nм VIP caused virtually no response. Interestingly, preincubation of PC12 cells with $\mathrm{H}-89$ did not alter the subsequent change in morphology induced by VIP. In parallel studies, the effect of various concentrations of $\mathrm{H}-89$ on the morphological appearance induced by VIP (Fig. 5) were compared to that of induction of CAT activity under NPY promoler control (Fig. 1B). The morphological effects of VIP could not be blocked by preincubation of PC12 cells with $\mathrm{H}-89$ even at a concentration (30 $\mu \mathrm{M})$ which completely reversed the effect of VIP on the activity of the NPY-CAT fusion gene (Figs. 1 $B, 5$ ). Higher concentrations of $\mathrm{H}-89$ killed $\mathrm{PCl} 2$ cells. In view of the minor inhibition by calphostin C of VIP and forskolin stimulated activity of the NPY-CAT fusion gene, the effect of this inhibitor alone and in combination with H-89 on VIP induced differentiation was assessed. No inhibition of differentiation was observed. Addition of PACAP38 (5 nM) or PACAP27 (5 nM) resulted in a similar

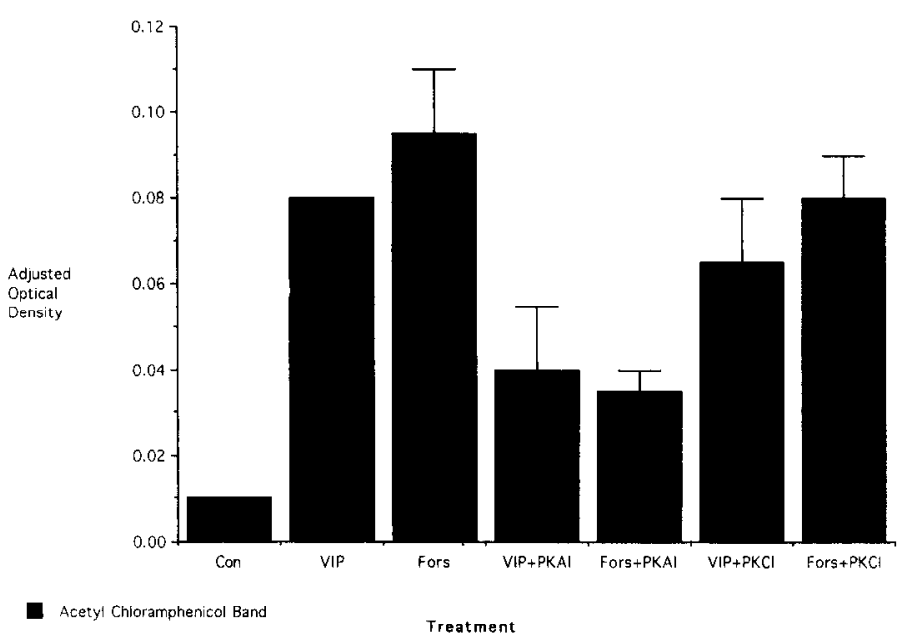

Figure 3. Comparison of effects of VIP and forskolin on NPY gene promoter activity. Acetyl chloramphenicol bands were scanned to measure the optical density. Results represent mean of duplicates and are typical of three separate experiments. Con, untreated cells; VIP, vasoactive intestinal peptide $(5 \mu \mathrm{M}) ;$ Fors, forskolin $(20 \mu \mathrm{M}) ; V I P+P K A I$, cells preincubated with $10 \mu \mathrm{M} \mathrm{H}-89$ prior to addition of VIP $(5 \mu \mathrm{M})$; Fors $+P K A I$, cells preincubated with $10 \mu \mathrm{M} \mathrm{H}-89$ prior to addition for forskolin $(20 \mu \mathrm{M}) ; V I P+P K C I$, cells preincubated with $1 \mu \mathrm{M}$ Calphostin $C$ prior to addition of VIP $(5 \mu \mathrm{M}) ;$ Fors $+P K C I$, cells preincubated with $1 \mu \mathrm{M}$ Calphostin $\mathrm{C}$ prior to addition of forskolin $(20 \mu \mathrm{M})$.

pattern of morphological differentiation, over the same time span. PACAP16-38 (5 nM to $5 \mu \mathrm{M})$ resulted in no altcration in appearance of $\mathrm{PC} 12$ cells.

The morphological change induced by VIP appeared distinct from that produced by NGF (Fig. 6). The neuronal processes

\section{EFFECT OF PACAP AND TWO PACAP FRAGMENTS ON NPY PROMOTER ACTIVITY}

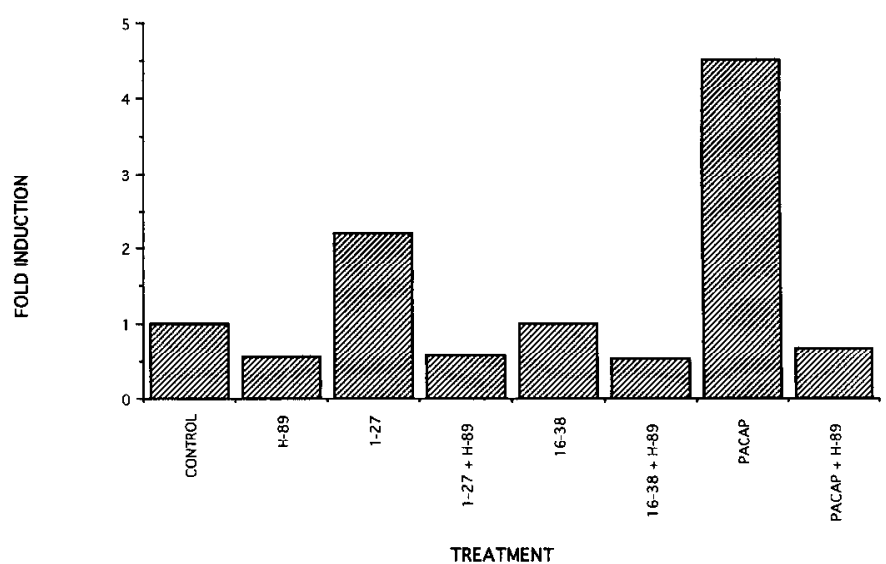

Figure 4. Comparison of the effect of various fragments of PACAP on NPY gene transcription. Results represent the mean of duplicates and are typical of three separate experiments. CONTROL, untreated cells; $H-89$, cells preincubated with $\mathrm{H}-89(10 \mu \mathrm{M}) ; 1-27$, cells treated with N-terminal fragment of PACAP (50 pM); $1-27+H$-89, cells pretreated with $\mathrm{H}-89(10 \mu \mathrm{M})$ prior to addition of N-terminal fragment of PACAP (50 pM); $16-38$, cells treated with C-terminal fragment of PACAP (50 pM); $16-38+H-89$, cells pretreated with $\mathrm{H}-89(10 \mu \mathrm{M})$ prior to addition of C-terminal fragment of PACAP; $P A C A P$, cells treated with 1-38 full-length peptide (50 pM); $P A C A P+H-89$, cells pretreated with $\mathrm{H}-89(10 \mu \mathrm{M})$ prior to treatment with full-length (1-38) PACAP. 

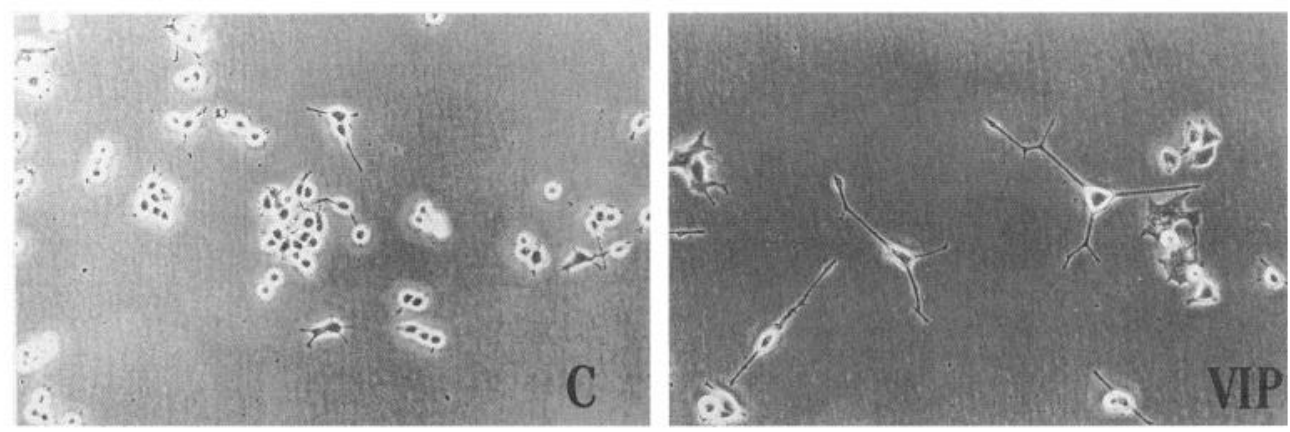

Figure 5. Effect of VIP $(5 \mu \mathrm{M})$ on morphological appearance of $\mathrm{PC} 12$ cells. $C$, untreated cells; VIP, $5 \mu \mathrm{M}$ VIP for $2 \mathrm{~d}$; $V I P+$ Inh 10 , cells pretreated for $1 \mathrm{hr}$ with $10 \mu \mathrm{M} \mathrm{H}-89$ prior to addition of VIP; VIP + Inh 30 , cells pretreated with $30 \mu \mathrm{M} \mathrm{H}-89$ prior to addition of VIP (5 $\mu \mathrm{M})$.
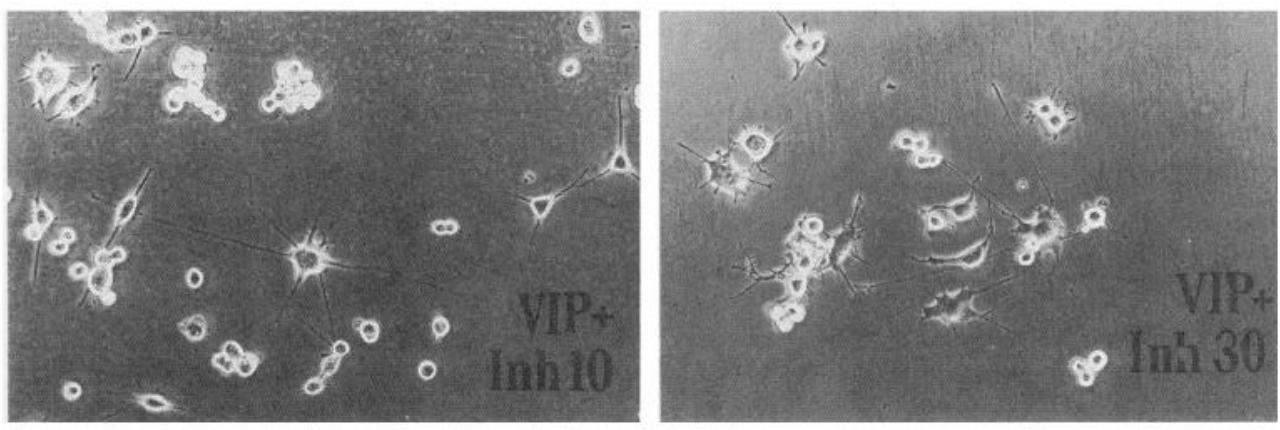

induced by NGF appeared more stubby than those following incubation with VIP at equivalent time points. Unlike the NGF induced changes in morphology, only a subpopulation of the PC1 2 cells (approximately half of the cells) underwent this change following addition of VIP. Addition of NGF and VIP simultaneously to the PC12 cells caused the cells to adopt some of the characteristics of both differentiation agents (Fig. 6D). Thus, the appearance of the neurites was more characteristic of that observed for VIP alone, as these appeared long and slender with bulbous growth cones. However, the cell bodies appeared much enlarged compared to VIP alone, and were more in keeping with the changes observed after NGF. Interestingly, although nearly all the cells apparently responded to NGF alone in terms of differentiation, when NGF and VIP were added simultaneously, only half the cells appeared to differentiate into neuronal phenotype.

\section{Discussion}

In this report, we examine the role of VIP in regulating transcriptional activity of the NPY gene, in particular the influence of various second messenger systems. Previous studies have shown that VIP induces expression of the gene for TH in PC12 cells (Wessels-Reikeretal, 1991). A role for this peptide in transsynaptic regulation of the TH activity has been implied by the findings that VIP-IR is present in cells of the intemediolateral column and in nerve terminals of postganglionic sympathetic nerves and adrenal medulla (Krukoff, 1986; Sasek and Zigmond, 1989; Yoshikawa et al., 1990). Transsynaptic activation of TH is now well recognized and some studies have indicated that similar processes may regulate NPY gene activity (Schalling et al., 1989; Hanze et al., 1991). However, although noncholinergic factors have been implicated in this regulation (Schalling et al., 1991), little is known of the nature of these agents mediating these responses. Our findings here demonstrate that VIP is capable of inducing NPY gene expression and that the concentration threshold required to achieve this response is equivalent to previous studies of TH mRNA induction (Wessels-Reiker et al., 1991).

Our study has shown that the related peptide PACAP also stimulates NPY gene expression. PACAP (Arimura, 1992) is a 38 amino acid peptide originally isolated from the bovine pituitary. The N-terminal 28 residues are similar in sequence to VIP, being $68 \%$ homologous. As the 28 th amino acid of PACAP is a glycine residue followed by two basic amino acids, it has been suggested that PACAP38 is cleaved to yield PACAP27amide. Our results indicate, first, that PACAP38 was considerably more potent than VIP in stimulating NPY gene transcription and, second, that activity resided in the $\mathrm{N}$-terminal fragment of the peptide. The difference in threshold of response of VIP compared to PACAP strongly suggests that these effects are mediated through the presence of a receptor for PACAP on PC1 2 cells, and that VIP may be acting through this receptor by virtue of its similar sequence. Recently, high-affinity receptors for PACAP have been found in the rat adrenal medulla (Shivers et al., 1991) and the cDNA encoding this receptor has been identified and characterized from a library constructed from adrenal mRNA (Morrow et al., 1993). These findings raise the possibility that PACAP is the factor involved in transsynaptic activation of postganglionic sympathetic structures, although, as yet, there are no reports detailing the presence of PACAP in preganglionic structures. It is possible that the previously reported VIP-IR may represent cross-reactivity of antisera raised to VIP with the related peptide, PACAP. Both peptides may be present and active in preganglionic autonomic transmission as preliminary reports have shown that infusion of PACAP releases catecholamines from rat adrenal glands and PACAP-immunoreactivity can be measured in plasma during electrical stimulation of the splanchnic nerves (Wakade et al., 1992).

Both VIP and PACAP appear to alter NPY gene transcription through the activation of PKA, as the responses were completely reversed by the addition of $\mathrm{H}-89$, an inhibitor of cAMP-depen- 

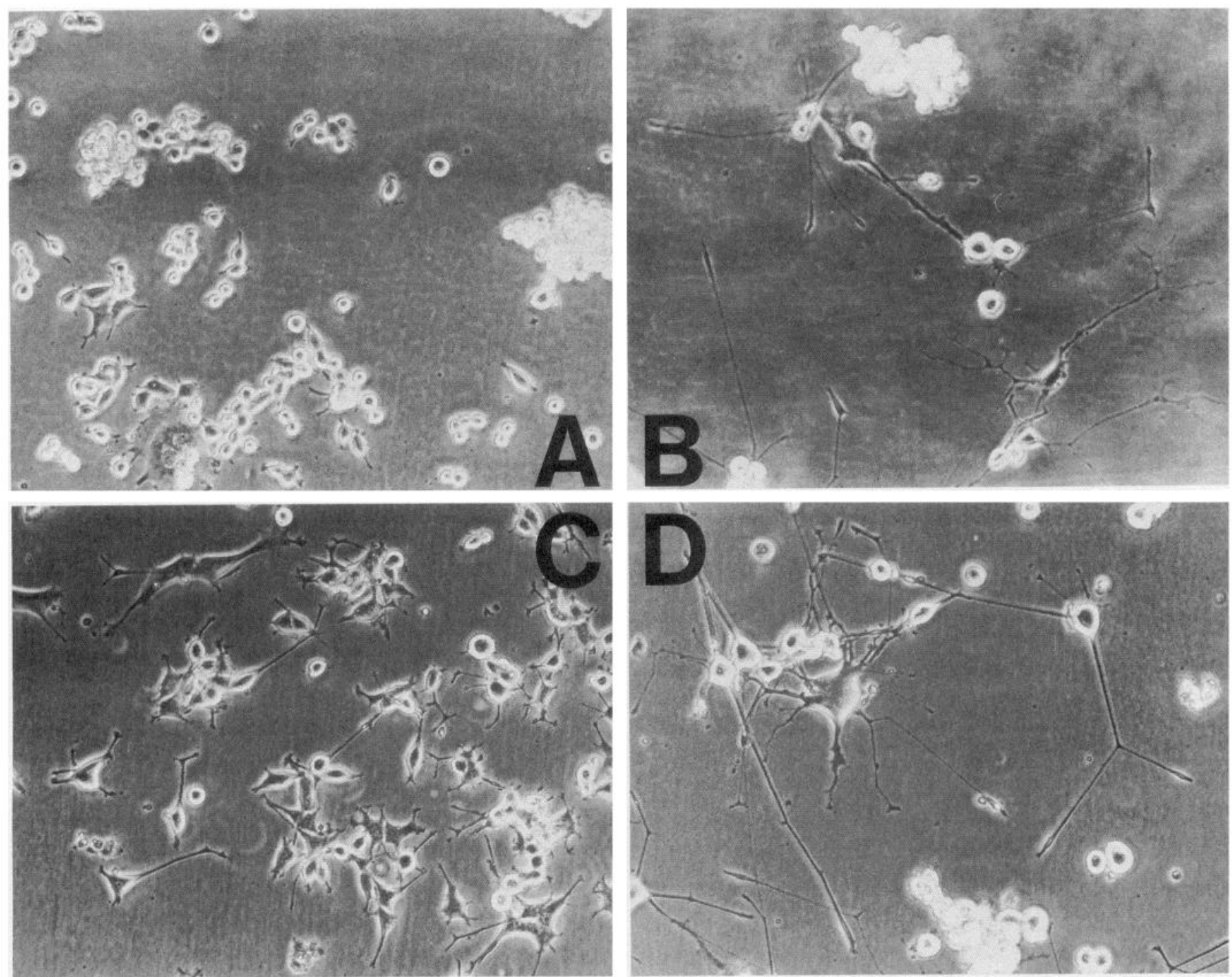

Figure 6. Comparison of the morphological response of PC12 cells to VIP and NGF. Cells were incubated for an additional $2 \mathrm{~d}$ after adding the various agents. $A$, control cells; $B$, cells treated with VIP $(5 \mu \mathrm{M}) ; C$, cells treated with NGF $(50 \mathrm{ng} / \mathrm{ml}) ; D$, cells treated with NGF (50 ng/ml) and VIP $(5 \mu \mathrm{M})$.

dent protein kinase (PKA). The response could also be mimicked by addition of forskolin. Both VIP and PACAP are known to activate adenylate cyclase in other systems (Said, 1982; Arimura, 1992). The response of the NPY gene occurs even in the absence of a cAMP response element (CRE) consensus sequence in the $5^{\prime}$ flanking region of the gene. Examination of the gene sequences reveals two AP-2 sites (Balbi and Allen, 1994) that, in other systems, can mediate responses to cAMP (Roesler et al., 1988). Specific deletion of these will be necessary to define the role of these AP- 2 sites in controlling NPY gene transcription in response to cAMP. Calphostin C, a specific inhibitor of PKC, caused a small but consistent reduction in the increase in NPY gene transcription induced by both VIP and forskolin indicating that these peptides may also activate phospholipase C. Alternatively, it may indicate cross talk between the two kinase systems (Yoshimasa et al., 1987).

A trophic role for VIP has been suggested by previous studies using cultured sympathetic neuroblasts (Pincus et al., 1990). Our study has shown that PC12 cells adopt a distinctive morpho- logical appearance in response to both VIP and PACAP, thus providing further evidence for a trophic role for these peptides in the sympathetic nervous system. The pattern induced by VIP and PACAP appeared different to that following NGF, and was similar to that induced by either forskolin or dibutyryl cAMP. Thus, it seems likely that the action on morphological differentiation induced by VIP and PACAP is explicable by the activation of adenylate cyclase and it may not be necessary to postulate the existence of a separate "trophic" receptor, as has been proposed for angiotensin II (Bottari et al., 1993). In keeping with this, VIP appears to exert its neurotrophic effect on rat sympathetic neuroblasts through cAMP (Pincus et al., 1990). However, the effect on VIP and PACAP on morphological appearance is independent of PKA or PKC unlike their effect on NPY gene transcription. The precise mechanism of the VIP or PACAP induced morphological changes remains unclear in the absence of any dependence on phosphorylation mediated by PKA. cAMP has recently been shown to have a direct effect on the hyperpolarization-activated current in cardiac pacemaker 
cells, suggesting direct activation by cAMP of an ion channel (DiFrancesco and Tortora, 1991). Similar channels have been described in some neurones (Bobker and Williams, 1989), although it is not known whether, in these neurones, the channels are also capable of directly binding cAMP. Direct activation of ion fluxes by cAMP may mediate the change in morphological appearance through stimulation of proto-oncogenes (Morgan and Curran, 1986, 1991). In neuroblastoma cells, PACAP has been shown to increase cytosolic calcium through both release from intracellular stores and entry of external calcium (Delporte et al., 1992). However, the dependence of this response on phosphorylation by PKA was not addressed. The proto-oncogene ras (Barbacid, 1987), has been implicated in mediating neuronal differentiation (Borasio et al., 1989) (Bar-Sagi and Feramisco, 1985 ) but this protein has been associated more with the tyrosinc kinase activated pathways of the growth factor receptors (Egan and Weinberg, 1993). Recent studies have demonstrated that cAMP in some cell lines interferes with the ras pathway activated by tyrosine kinase receptors. However, the evidence indicates that this effect of cAMP is mediated by PKA phosphorylation of Raf-1 (Cook and McCormick, 1993) (Wu et al., 1993). Thus, a similar cross talk mechanism cannot account for the findings of this study, where inhibitors of PKA had no effect on the morphological changes induced by VIP/PACAP. There remains the possibility that VIP/PACAP are mediating their effects on morphology through a separate signaling pathway, independent of PKA. A recent study using in vitro autoradiography has proposed that there are multiple VIP receptors in the developing mouse embryo, of which one is insensitive to GTP (Gressens et al., 1993).

The change to a neuronal pattern of morphology observed in PC12 cells following the addition of VIP or PACAP suggests that these peptides may play an important trophic role in the CNS and PNS, in addition to the accepted neurotransmitter function of VIP in postganglionic parasympathetic nerves. VIPIR has been demonstrated in the early developing brain and spinal cord (Maletti et al., 1980; Fuji et al., 1985), although levels of detectable immunoreactivity are low in embryonic tissues. However, high levels of VIP receptors are found in the CNS during development and in mouse embryo explants (Gressens et al., 1993). The peptide has been shown to have profound effects on embryonic growth, in vitro (Gressens et al., 1993) and on sympathetic neuroblasts derived from foetal rats of $15.5 \mathrm{~d}$ gestation (Pincus et al., 1990) indicating that the receptors are present on target tissue at the appropriate time in development. A number of additional studies have shown that VIP promotes neuronal survival in vitro (Brenneman ct al., 1985; Gozes and Brenneman, 1993) and causes neurite extension of neurones from ventral spinal cord of embryonic rats (Iwasaki et al 1990). Thus, it is possible that, within preganglionic sympathetic nerves, the trophic role of these peptides may be their primary action in the developing nervous system, whereas their regulation of sympathetic nerve function may occur later once the specialized environments are achieved by high steroid input to the adrenal medulla and the establishment of NGF dependence in the sympathetic nervous system.

\section{References}

Allen JM, Bircham PM, Bloom SR, Edwards AV (1984) Release of neuropeptide $\mathrm{Y}$ in response to splanchnic nerve stimulation of the conscious calf. J Physiol (Lond) 357:401-408.

Arimura A (1992) Pituitary adenylate cyclase activating polypeptide
(PACAP): discovery and current status of research. Regul Peptides 37:287-303.

Ashe JH, Libet B (1981) Orthodromic production of non-cholinergic depolarizing response in the superior cervical ganglion of the rabbit. J Physiol (Lond) 320:333-336.

Balbi D, Allen JM (1994) Role of protein kinase C in mediating NGF effects on neuropeptide $\mathrm{Y}$ expression in PC12 cells. Mol Brain Res 23:310-316.

Baldwin C, Sasek CA, Zigmond RE (1991) Evidence that some preganglionic sympathetic neurons in the rat contain vasoactive intestinal peptide-like or peptide histidine isoleucine amide-like immunoreactivities. Neuroscience 40:175-184.

Barbacid M (1987) ras genes. Annu Rev Biochem 56:779-827.

Bar-Sagi D, Feramisco JR (1985) Microinjection of the ras oncogene protein into PC12 cells induces morphological differentiation. Cell 42:841-848.

Bobker DH, William JT (1989) Serotonin augments the cationic current $I_{h}$ in central neurons. Neuron 2:1535-1540.

Borasio DG, John J, Wittinghofer A, Barde Y-A, Sendtner M, Heumann $R$ (1989) ras $p 21$ protein promotes survival and fiber outgrowth of cultured embryonic neurons. Neuron 2:1087-1096.

Bottari SP, de Gasparo M, Steckelings M, Levens NR (1993) Angiotensin II receptor subtypes: characterisation, signalling mechanisms and possible physiological implications. Front Neuroendocrinol 14: 123-171.

Brenneman DE, Eiden LE, Siegel RE (1985) Neurotrophic actions of VIP on spinal cord cultures. Peptides 6[Suppl 2]:35-39.

Chen SS (1971) Transmission in superior cervical ganglion of the dog after cholinergic suppression. Am J Physiol 221:209-213.

Colmers WF, Wahlestedt C (1993) The biology of neuropeptide Y. Clifton, NJ: Humana.

Cook SJ, McCormick F (1993) Inhibition of cAMP of ras-dependent activation of raf. Science 262:1069-1072.

Delporte C, Herchuelz A, van Praet A, Robberecht P, Winand J, Christopher J (1992) PACAP increases [Ca'+]; in singlc human ncuroblastoma NB-OK-1 cells. Regul Peptides P133.

DiFrancesco D, Tortora P (1991) Direct activation of cardiac pacemaker channels by intracellular cyclic AMP. Nature 351:145-147.

Egan SE, Weinberg RA (1993) The pathway to signal achievement. Nature 365:781-783.

Fuji K, Senba E, Fujii S, Nomura I, Wu J-Y, Ueda Y, Tohyama M (1985) Distribution, ontogeny and projections of cholecystokinin-8, vasoactive intestinal polypeptide and $\gamma$-aminobutyrate-containing neuron systems in the rat spinal cord: an immunohistochemical analysis. Neuroscience 14:881-894.

Gozes I, Brenneman DE (1993) Neuropeptides as growth and differentiation factors in general and VIP in particular. $\mathbf{J}$ Mol Neurosci $4: 1-7$.

Greenberg ME, Greene LA, Ziff EB (1985) Nerve growth factor and epidermal growth factor induce rapid transient changes in proto-oncogene transcription in PC12 cells. J Biol Chem 260:14101-14110.

Greene LA, l'ischler AS (1976) Establishment of a noradrenergic clonal line of the rat adrenal pheochromocytoma cells which respond to nerve growth factor. Proc Natl Acad Sci USA 73:2424-2428.

Gressens P, Hill JM, Gozes I, Fridkin M, Brenneman DE (1993) Growth factor function of vasoactive intestinal peptide in whole cultured mouse embryos. Nature 362:155-158.

Hanze J, Kummer W, Haass M, Lang RE (1991) Neuropeptide Y messenger RNA regulation in rat sympathetic ganglia-effect of reserpine. Neurosci Lett 124:119-121.

Ip NY, Ho CK, Zigmond RE (1982) Secretin and vasoactive intestinal peptide acutely increase tyrosine 3-monooxygenase in the rat superior cervical ganglion. Proc Natl Acad Sci USA 79:7566-9756.

Ip NY, Baldwin C, Zigmond RE (1985) Regulation of the concentration of adenosine 3 ' 5'-cyclic monophosphate and the activity of tyrosine hydroxylase in the rat superior cervical ganglion by three neuropeptides of the secretin family. J Neurosci 5:1947-1954.

Iwasaki Y, Kinoshita M, Ikeda K, Shiomjima T (1990). Neurotrophic effect of vasoactive intestinal polypeptide on the ventral spinal cord of rat embryo. Acta Neurol Scand 81:87.

Kilbourne EJ, Nankova BB, Lewis EI, McMahon A, Osaka H, Sabban DB, Sabban EL (1992) Regulated expression of the tyrosine hydroxylase gene by membrane depolarization. J Biol Chem 267:75637569.

Kingston RE (1987) In: Current protocols in molecular biology (Au- 
subel FM; Brent R, Kingston RE, Moore DD, Seidman JG, Smith JA, Struhl K, eds). New York: Wiley Interscience.

Krukoff TL (1986) Segmental distribution of corticotrophin- releasing factor-like and vasoactive intestinal peptide-like immunoreactivities in presumptive sympathetic preganglionic neurons of the cat. Brain Res 382:153-157.

Larhammar D, Ericsson A, Persson H (1987) Structure and expression of the rat neuropeptide Y gene. Proc Natl Acad Sci USA 84:20682072.

Maletti M, Besson J, Bataille D, Laburthe M, Rosselin G (1980) Ontogeny and immunoreactive forms of vasoactive intestinal peptide (VIP) in rat brain. Acta Endocrinol 93:479-487.

Malhotra RK, Wakade AR (1987) Vasoactive intestinal polypeptide stimulates the secretion of catecholamines from the rat adrenal gland. J Physiol (Lond) 388:285-294.

Malhotra RK, Wakade TD, Wakade AR (1988) Vasoactive intestinal polypeptide and muscarine mobilize intracellular $\mathrm{Ca}^{2+}$ through breakdown of phosphoinositides to induce catecholamine secretion. J Biol Chem 263:2123-2126.

Malhotra RK, Blank M, Wakade TD, Wakade AR (1989) Vasoactive intestinal polypeptide (VIP) serves as another neurotransmitter in the adrenal. Regul Peptides 26:168.

McDonald JK (1988) NPY and related substances. CRC Crit Rev Neurobiol 4:97-135.

McKeon TW, Zigmond RE (1993) Vasoactive intestinal peptide and secretin produce long term increases in tyrosine hydroxylase activity in the rat superior ganglion. Brain Res 607:345-348.

Misbahuddin M, Oka M, Nakanishi A, Morita K (1988) Stimulatory effect of vasoactive intestinal polypeptide on catecholamine secretion from isolated guinea pig adrenal chromaffin cells. Neurosci Lett 92: 202-206.

Morgan JI, Curran T (1986) The role of ion flux in the control of $c$-fos expression. Nature 322:552-555.

Morgan JI, Curran T (1991) Stimulus-transcription coupling in the nervous system: involvement of the inducible proto-oncogenes fos and jun. Annu Rev Neurosci 14:421-451.

Morrow JA, Lutz EM, West KM, Fink G, Harmar AJ (1993) Molecular cloning and expression of a cDNA-encoding a receptor for pituitary adenylate cyclase activating polypeptide (PACAP). FEBS Lett 329: 99-105.

Nishi S, Koketsu K (1968) Early and late after discharges of amphibian sympathetic ganglion cells. J Neurophysiol 313:109-130.

Pincus DW, DiCicco-Bloom EM, Black IB (1990a) Vasoactive intestinal peptide regulates mitosis, differentiation and survival of cultured sympathetic neuroblasts. Nature 343:564-567.

Pincus DW, DiCicco-Bloom EM, Black IB (1990h) Vasoactive intestinal peptide regulation of neuroblast mitosis and survival-role of cAMP. Brain Res 514:355-357.

Potter EK (1988) Neuropeptide $Y$ as an autonomic transmitter. Pharmacol Ther 37:251-273.

Roesler WJ, Vandenbark GR, Hanson RW (1988) Cyclic AMP and the induction of eukaryotic gene transcription. J Biol Chem 263:90639066.

Roskoski R, White L, Knowlton R, Roskoski LM (1989) Regulation of tyrosine hydroxylase activity in rat $\mathrm{PCl} 2$ cells by neuropeptides of the secretin family. Mol Pharmacol 36:925-931.

Sabol S, Higuchi H (1990) Transcriptional regulation of the neuropeptide $Y$ gene by nerve growth factor: antagonism by glucocorticoids and potentiation by adenosine $3^{\prime}, 5^{\prime}$ monophosphate and phorbol ester. Mol Endocrinol 4:384-392.
Said SI (1982) Advances in peptide hormone research series, Vasoactive intestinal peptide. New York: Raven.

Sasek CA, Zigmond RE (1989) Localization of vasoactive intestinal peptide-like and peptide histidine isoleucine amide-like immunoreactivities in the rat superior cervical ganglion and its nerve trunks. J Comp Neurol 280:522-532.

Schalling M, Stieg PE, Lindquist C, Goldstein M, Hokfelt T (1989) Rapid increase in enzyme and peptide messenger RNA in sympathetic ganglia after electrical stimulation in humans. Proc Natl Acad Sci USA 86:4302-4305.

Schalling M, Franco-Cereceda A, Hemson A, Dagerlind A, Seroogy K, Persson H, Hokfelt T, Lundberg JM (1991) Neuropeptide Y and catecholamine synthesising enzymes and their mRNAs in rat sympathetic neurons and adrenal glands: studies on expression, synthesis and axonal transport after pharmacological and experimental manipulations using hybridization techniques and radioimmunoassay. Neuroscience 41:753-766.

Shimamoto H, Shimamoto Y, Kwan C.-Y, Daniel EE (1992) Participation of protein kinase $C$ in endothelin-1-induced contraction in rat aorta: studies with a new tool, calphostin $\mathrm{C}$. $\mathrm{Br} \mathrm{J}$ Pharmacol 107 282-287.

Shivers BD, Goves TJ, Gottschall PE, Arimura A (1991) Two high affinity binding sites for pituitary adenylate cyclase activating polypeptide have different tissue distributions. Endocrinology 128:30553065 .

Tatemoto K (1982) Neuropeptide Y: complete amino acid sequence of the brain peptide. Proc Natl Acad Sci USA 79:5485-5489.

Varndell IM, Polak JM, Allen JM, Terenghi G, Bloom SR (1984) Neuropeptide tyrosine (NPY)-immunoreactivity in norepinephrinecontaining cells in the mammalian adrenal gland. Endocrinology 114: 1460-1462.

Volle RL, Patterson BA (1982) Regulation of cyclic AMP accumulation in rat sympathetic ganglion-effects of vasoactive intestinal polypeptide. J Neurochem 39:1195-1197.

Wakade AR, Guo X, Strong R, Arimura A, Haycock J (1992) Pituitary adenylate cyclase activating polypeptide (PACAP) as a neurotransmitter in the rat adrenal medulla. Regul Peptides 37:331.

Wang YN, Chou J, Zhu YX, Chang D, Chang JK (1992) Distribution and characterization of pituitary adenylate cyclase-activating polypeptide (PACAP) in various rat tissues and in plasma. Regul Peptides 37:327.

Wessels-Reiker M, Haycock JW, Howlet AC, Strong R (1991) Vasoactive intestinal polypeptide induces tyrosine hydroxylase in $\mathrm{PC} 12$ cells. J Biol Chem 266:9347-9350.

Wu J, Dent P, Jelinek T, Wolfman A, Weber MJ, Sturgill TW (1993) Inhibition of the EGF-activated MAP kinase signaling pathway by adenosine 3',5'-monophosphate. Science 262:1065-1069.

Yoshikawa M, Saito H, Sano T, Ohuchi T, Ishimura Y, Morita K, Saito $S$, Oka M (1990) Localization and release of immunorcactive vasoactive intestinal polypeptide in bovine adrenal medulla. Neurosci Lett 111:75-77.

Yoshimasa T, Sibley DR, Bouvier M, Lefkowitz RJ, Caron MG (1987) Cross talk between cellular signalling pathways suggested by phorbol ester induced adenylate cyclase phosphorylation. Nature 327:67-70.

Zigmond RE, Schwarzchild MA, Rittenhouse AR (1989) Acute regulation of tyrosine hydroxylase by nerve activity and by neurotransmitters via phosphorylation. Annu Rev Neurosci 12:415-461. 